\title{
The renin-angiotensin system and the heart: a historical review
}

\author{
Stephen J Cleland, John L Reid
}

\section{Early observations on a possible link between the kidney and the cardiovascular system}

In 1836 an English clinician Richard Bright observed that patients dying with contracted kidneys often had a hard, full pulse and cardiac hypertrophy. ${ }^{1}$ In 1889 Brown-Sequard, the "father" of endocrinology, showed that injections of extracts from guinea pig testicles were able to produce systemic effects of vigour and the perception of rejuvenation. ${ }^{2}$ On this background, in 1896 the Finnish physiologist Robert Tigerstedt and his student Per Bergman began to explore the possibility that kidney extracts from rabbits may have some systemic effects on the cardiovascular system. In 1898 their classic paper was published showing that intravenous injection of these renal extracts exerted a pressor effect. Moreover they postulated that the substance responsible for this effect was a protein which they named renin. They further suggested that renin was released from the kidney into the blood to produce an effect on blood vessels at a distance: another of the earliest ideas on blood borne chemical messengers. ${ }^{34}$ Eight years later Tigerstedt described a pressor effect of renal venous blood although he admitted that the evidence for this was weak. ${ }^{5}$ Other groups could not reproduce Tigerstedt's results, probably because they failed to prevent proteolysis in the preparation of the renal extracts. Therefore enthusiasm for the concept of renin as a pressor substance waned. Tigerstedt died in 1923 without any real acknowledgment of the significance of his contribution to the fields of both endocrinology and cardiovascular homeostasis. In fact for 30 years there were few references to the pressor effects of renin in the literature. In 1925, the histologist Ruyter was the first to describe granulated cells in the walls of the glomerular arterioles. ${ }^{6}$ The significance of this was realised by Goormaghtigh in $1939^{7}$ after the concept of renin as a hormone had been rekindled.

Department of Medicine and Therapeutics, Gardiner Institute, Western Infirmary, Glasgow, Scotland $\mathrm{S} J$ Cleland

$\mathrm{J}$ L Reid

Correspondence to: Dr Stephen J Cleland, Department of Medicine and Therapeutics, Gardiner Institute, Western Infirmary, Glasgow G11 6NT, United Kingdom. effect, ${ }^{10}$ confirming Tigerstedt's 40 year results. Braun-Menendez and colleagues ${ }^{11}$ and Page and colleagues ${ }^{12}$ proposed that renin itself was not directly responsible for its pressor effect but was in fact an enzyme. The names "hypertensin" 11 and "angiotonin" 12 were given to the pressor substance formed from the renin substrate by the enzymatic action of renin. Subsequently, it was agreed that the term "angiotensin" would be used to describe this substance. During this period the potential for pathological effects of renin was recognised. Winternitz described necrotising arteriolar lesions in animals which had undergone renal artery ligation and also in nephrectomised animals which had been given kidney extracts. ${ }^{13}$ Finally, the relevance of renal control of blood pressure in man was described by Young who, in 1936, cured a case of malignant hypertension by removing an ischaemic kidney. ${ }^{14}$

\section{The elucidation of the renin-angiotensin} system

In 1956, Elliott and Peart ${ }^{15}$ and Skeggs and colleagues $^{16}$ discovered that the product of renin action was a decapeptide which required further enzymatic breakdown to form the active pressor substance, an octapeptide. Based on these results the terms angiotensin I, angiotensin II, and angiotensin converting enzyme (ACE) were coined. In the following year the structure of renin substrate was shown to be a tetradecapeptide ${ }^{17}$ which was later referred to as angiotensinogen. Concurrent with the discovery of the structure for angiotensinogen, angiotensin II was synthesised $^{18}$ which enabled further definition of its actions. However, it was not until the early 1970 s that the mechanism of action of renin, as an acid protease with very narrow substrate specificity, was described. ${ }^{19}$

Meanwhile the idea of a relation between the renin-angiotensin system and the adrenal cortex was evolving. In 1953, aldosterone was discovered. ${ }^{20}$ The following year Gross showed an enhanced pressor response to renin in animals with bilateral nephrectomy and in those with "DOCA-salt" induced hypertension. Another group observed that the amount of granules in the juxtaglomerular apparatus correlated with the width of the zona glomerulosa of the adrenal cortex. ${ }^{21}$ In 1956, Gross showed that the amount of renin in the juxtaglomerular apparatus was inversely proportional to the sodium balance; two years later he went on to suggest that the renin-angiotensin system participated in a negative feedback mechanism with the adrenal cortex to control sodium metabolism. ${ }^{22}$ Subsequent studies confirmed this hypothesis. Renin and angiotensin II were shown to stimulate aldosterone secretion in sheep $^{23}$ and in dogs. ${ }^{24-26}$ Laragh found increased urinary aldosterone excretion in man 
during infusion of angiotensin $\mathrm{II} .{ }^{27}$ Brown and colleagues showed that a low sodium diet in man led to a raised plasma renin concentration $^{28}$ and vice versa. They also described a plasma renin concentration of 10 times that of normal concentrations in a patient with Addison's disease. ${ }^{29}$

The increasing ability to accurately measure the various components of the reninangiotensin-aldosterone system allowed further studies to be conducted to confirm Gross's hypothesis. Assays for plasma aldosterone levels $^{30}$ and plasma renin activity ${ }^{31}$ were described and the development of radioimmunoassays to measure angiotensin I, angiotensin II, and plasma renin concentrations followed. ${ }^{3233}$ Using these techniques, studies performed in the human showed that salt depletion resulted in increased plasma levels of angiotensin $\mathrm{II}^{34}$ as well as sensitising the secretion of aldosterone to angiotensin II. ${ }^{35}$

Through these studies, which spanned a period of 25 years, the concept became established that the renin-angiotensin system was an endocrine pathway linked to aldosterone secretion by the adrenal cortex. This pathway provided a homeostatic control mechanism for sodium balance, intravascular volume, and therefore blood pressure. It also became apparent that angiotensin II influenced blood pressure directly by its vasoconstrictor effect and also by an independent more slowly developing pressor mechanism..$^{36} 37$

Early evidence of a link between the reninangiotensin system and cardiac function

In 1956 it was shown that patients who had suffered a myocardial infarction had increased amounts of urinary aldosterone. ${ }^{38}$ Thirty years later it was confirmed that the renin-angiotensin system is stimulated in man following myocardial infarction, although it was shown that there was a delay in this stimulation with a peak at approximately three days after the infarction. ${ }^{39}$ In 1972, a study was published which suggested that patients with essential hypertension who had low renin values were at lower risk for subsequent myocardial infarction. ${ }^{40}$ Although the interpretation of these results is still a source of controversy, further results from the same group appear to support the idea that reduced stimulation of the reninangiotensin system in conjunction with hypertension may protect against ischaemic heart disease. ${ }^{41}$

Evidence began to accumulate that angiotensin II had a direct positive inotropic effect on the heart despite often being masked by increased cardiac afterload in experimental conditions. This effect was first noted in $1965^{42}$ and has subsequently been confirmed. ${ }^{4344}$ The potential harmful effects of angiotensin II on the heart have also been recorded ${ }^{45}$ and multifocal myocardial necrosis has been demonstrated in rabbits injected with angiotensin II. In these studies necrotic lesions were shown to be most severe in the left ventricle of rabbits as well as in the presence of coexisting hypertension, suggesting an interaction of pressure and workload factors. ${ }^{46}$
In 1975, it was shown that renin release in dogs was modulated by cardiopulmonary receptors. ${ }^{47}$ Further studies revealed that intravenous injections of rat atrial extract induced natriuresis. ${ }^{48}$ Results from these studies led to the isolation of atrial natriuretic factor (ANF) which was found to modulate renin release in a dose dependent fashion. The modulation of renin release by ANF was dependent upon underlying sodium balance and renal function. ${ }^{49}$ In the context of congestive cardiac failure high concentrations of ANF have been found in man..$^{50}$

Two concepts started to emerge concerning the link between the renin-angiotensin system and cardiac function. First, myocardial function was affected by the renin-angiotensin system directly and not simply as an indirect result of blood pressure changes. Second, the heart was able to modulate renin release through ANF and therefore played an integral role in the homeostatic control of intravascular volume and sodium balance.

The contribution of antagonists and inhibitors to the understanding of the renin-angiotensin system

In 1965 , it was noted that venom from a Brazilian viper potentiated the effects of bradykinin. ${ }^{51}$ An enzyme had been described a few years earlier which inactivated bradykinin ${ }^{52}$ leading to the presumption that substances contained in the snake venom were kininase inhibitors. Meanwhile it was found that peptides from the same venom were able to inhibit ACE. ${ }^{53}$ From this work emerged the nonapeptide teprotide, which was the first widely used ACE inhibitor. Teprotide was shown to lower blood pressure in rats with induced hypertension $^{54}$ and in sodium depleted dogs. ${ }^{55}$ The race to develop an orally active agent began and eventually SQ14225 emerged, later to be known as captopril. In the early 1970 s it became clear that ACE and kininase were the same enzyme, ${ }^{56}$ a finding which may have important implications for the mechanisms of action of ACE inhibitors in the heart.

The discovery of competitive antagonist peptide analogues of angiotensin II was another important landmark. Saralasin was a widely used agent. ${ }^{57}$ The use of this peptide in experimental models uncovered the selective vasoconstrictor properties of angiotensin II; it appeared that a stimulated renin-angiotensin system resulted in vasoconstriction of cardiac, renal, and cerebral vascular beds. This may explain how inhibition of either formation or action of angiotensin II helps to maintain vital organ perfusion pressure even in the face of low systemic blood pressure. ${ }^{58}$ Saralasin was shown to lower blood pressure in sodium depleted dogs, ${ }^{59}$ to lower blood pressure and reverse left ventricular failure in malignant hypertension, ${ }^{60}$ and to lower blood pressure and aldosterone levels in proportion to basal angiotensin II levels. ${ }^{61}$ However, its use was restricted for two reasons; first it was not orally active and second it had partial agonist activity at higher concentrations. The search began for 
orally active specific antagonists of angiotensin II. ${ }^{62}$ Losartan, a drug fulfilling these criteria, became available for clinical use only recently. ${ }^{63}$

The final strategy for modification of the renin-angiotensin system lies in the inhibition of renin. While there has been progress, ${ }^{64}$ and some of the early inhibitors provided important information on the active site of renin, ${ }^{65}$ no clinically useful orally active renin inhibitor is available at present.

The use of ACE inhibitors in heart failure and the new interactions between the renin-angiotensin system and the heart

Captopril, by reducing the peripheral effects of angiotensin II, has a vasodilator effect. This was the original basis for its use in the treatment of essential hypertension and in this context it is as effective as either a $\beta$ blocker or a thiazide diuretic. ${ }^{66}$ Its use was extended to the treatment of congestive cardiac failure because of its vasodilating property; by reducing cardiac preload and afterload, systolic function improved. The beneficial effects of captopril in congestive heart failure were first noted in the late 1970s. ${ }^{6768}$ However, in subsequent studies it emerged that ACE inhibitors were more than simple peripheral vasodilators. In 1985, a study was published showing that enalapril, another ACE inhibitor, increased the survival rate of patients with congestive heart failure, whereas other types of vasodilators did not. ${ }^{69}$ This finding was confirmed in subsequent studies $^{7071}$ and was extended to include patients with asymptomatic left ventricular dysfunction. ${ }^{72}$ It was also shown that captopril increased survival in patients who were recovering from myocardial infarction..$^{73}$ Therefore it became clear that ACE inhibitors exerted unique effects on cardiac function.

\section{ACE INHIBITORS CAUSE REGRESSION OF LEFT} VENTRICULAR HYPERTROPHY IN HYPERTENSION One hundred and sixty years ago, left ventricular hypertrophy (LVH) was noted in conjunction with renal hypertension. ${ }^{1}$ Until recent years, LVH was assumed to be a mechanical compensatory mechanism in response to the increased cardiac afterload of hypertension. The importance of increased left ventricular mass as a risk factor for coronary events has been noted. ${ }^{74} 75$ It has been shown that ACE inhibitors cause regression of LVH in spontaneously hypertensive rats. ${ }^{76}$ Subsequent studies in humans have suggested that ACE inhibitors cause a significantly greater degree of regression of LVH than $\beta$ blockers or calcium antagonists despite similar falls in blood pressure, suggesting that ACE inhibitors may be exerting a direct negative trophic effect on the myocardium. ${ }^{77} \beta$ Blockers have some action on regression of LVH independent of blood pressure changes ${ }^{78}$ which may reflect the importance of the sympathetic nervous system in this context. It is now generally agreed that angiotensin II has a trophic effect on cardiac muscle. ${ }^{7980}$ Proposed mechanisms for this effect include stimulation of protein synthesis and cell growth in myocytes ${ }^{81} 82$ possibly by increased expression of proto-oncogenes and stimulation of protein kinase C activation. ${ }^{83} \mathrm{It}$ follows that ACE inhibition could induce regression of LVH by attenuation or reversal of these mechanisms.

\section{ACE INHIBITORS INCREASE CORONARY BLOOD} FLOW

Reference has already been made to the action of angiotensin II as a coronary vasoconstrictor. There is an increasing body of evidence concerning the participation of the reninangiotensin system in coronary vasomotor control. $^{84}$ For example, administration of a diuretic which enhances the renin-angiotensin system causes reduced coronary blood flow, an effect which is reversed by ACE inhibition. ${ }^{85}$ ACE inhibitors cause coronary vasodilatation in perfused heart preparations, ${ }^{86}$ and intracoronary injection of ACE inhibitors in humans results in increased coronary perfusion and a decreased ejection fraction. ${ }^{87}$ The fact that ACE inhibitors have the ability to increase coronary blood flow despite decreased myocardial oxygen demand ${ }^{88}$ is likely to be crucial to their beneficial effects in ischaemic left ventricular dysfunction. The effect of angiotensin II as a positive inotrope in the failing heart may be compromised by its other effects, namely, of decreasing coronary flow and increasing diastolic dysfunction, resulting in cardiac decompensation. ${ }^{89}$ In this regard ACE inhibitors have been shown to improve diastolic dysfunction in patients with ischaemic heart disease. ${ }^{90}$

\section{ACE INHIBITORS ATTENUATE SYMPATHETIC}

NERVOUS SYSTEM ACTIVITY IN THE HEART Angiotensin II has long been known to cause stimulation of the central ${ }^{91}$ and peripheral ${ }^{92}$ sympathetic nervous system as well as stimulating release of catecholamines. ${ }^{93}$ The latter two effects are mediated by facilitating prejunctional angiotensin II receptors on sympathetic nerves and adrenal medullary cells. Chronic overactivity of the sympathetic nervous system in conditions of left ventricular dysfunction is probably detrimental to long term cardiac function. This theory is supported by the beneficial effects of $\beta$ blockers in some patients with ischaemic heart disease and in the attenuation of $\mathrm{LVH}^{78}$ some of which is probably mediated by sympathetic nerve activity. The mechanisms by which angiotensin II stimulates the sympathetic nervous system are reviewed elsewhere. ${ }^{44}$ Recently further evidence has been provided that ACE inhibitors may exert some of their beneficial effects on the heart through inhibition of this sympathetic stimulation. ${ }^{94}$

The use of ACE inhibitors in myocardial infarction and the role of the reninangiotensin system in the regulation of endothelial function

Reference has already been made to the effect of myocardial infarction on stimulation of the renin-angiotensin system. ${ }^{38}{ }^{39}$ It has been postulated that angiotensin II in this context may 
have several unwanted effects; among these are intense vasoconstriction resulting in increased reperfusion injury ${ }^{95}$ and stimulation of sympathetic nerve activity resulting in a higher risk of arrhythmia. ${ }^{96}$ After a moderate to severe myocardial infarction, remodelling of the left ventricle takes place, which results in a more dilated ventricle with reduced functional capacity. ACE inhibitors given following myocardial infarction are known to reduce this process of remodelling; their mechanism is probably a combination of their haemodynamic and metabolic properties. ${ }^{97} 98$

More recently the kininase inhibiting property of ACE inhibitors has aroused interest within the context of cardioprotection. It has been shown that the administration of bradykinin antagonists abolishes the beneficial effects of ACE inhibitors in the ischaemic rat heart, ${ }^{99}$ and in hypertrophy. ${ }^{100}$ It has been postulated that locally elevated levels of bradykinin in the heart may be cardioprotective ${ }^{98}$ Recent research has documented the vasodilating and antiatherogenic roles of the endothelium derived nitric oxide system. Because bradykinin is a potent stimulus of this system, it is feasible that a major part of the beneficial effect of ACE inhibition may ultimately operate through enhancement of the nitric oxide system. Nitric oxide is known to have anti-trophic properties and therefore may be an important mediator in the development of $\mathrm{LVH} .^{100}$ It is a potent vasodilator acting on smooth muscle cells and therefore could be responsible for the effect of ACE inhibition on coronary blood flow. ${ }^{101}$ In addition, there is evidence for an antiatherogenic effect of long term ACE inhibition in a rabbit model ${ }^{102}$ and it has been shown that ACE inhibition prevents myointimal proliferation after vascular injury. ${ }^{103}$

It appears, therefore, that as well as having a secondary cardioprotective role, ACE inhibitors also have a role in primary cardioprotection. As stated previously in this review, long term reduced activation of the renin-angiotensin system in some patients with essential hypertension may protect them from subsequent myocardial infarction. ${ }^{40} 41$ In addition, it has recently been reported that individuals with a deletion polymorphism of the gene for ACE, and therefore who tend to have higher serum ACE concentrations, are at increased risk of myocardial infarction. ${ }^{104}{ }^{105}$ Prospective clinical trials designed to assess the effects of ACE inhibition on mortality and left ventricular function in various patient groups have also revealed that the incidence of myocardial infarction is reduced in the treated groups. ${ }^{71-73}$ Kininase inhibition through the endothelium derived nitric oxide system and its inherent vasodilator and antiatherogenic properties may be another mechanism by which ACE inhibitors play a cardioprotective role. ${ }^{89}$

\section{Evidence for a cardiac renin-angiotensin} system

In the early 1970 s, evidence was presented which suggested that the heart might have its own intrinsic renin-angiotensin system. This evidence also supported the theory that the heart was able to respond to change in the circulating humoral system; renin activity was demonstrated in dog heart ${ }^{106}$ and conversion of angiotensin I to angiotensin II was noted in isolated perfused heart preparations. ${ }^{107}$ Interest in an intrinsic cardiac renin-angiotensin system was further stimulated by the elucidation of the mechanisms of action of ACE inhibitors on the heart. Despite very little change in the systemic indices of the reninangiotensin system during ACE inhibition, the beneficial effects on the heart remain. This suggests that inhibition of angiotensin II and bradykinin production is occurring predominantly in the heart, ${ }^{108}$ and that ACE inhibition may be most effective at a local level. This concept is supported by the fact that ACE inhibitors still have effects when perfused in isolated heart preparations. ${ }^{86}$

Important evidence for a local reninangiotensin system in the heart is the presence of ACE, ${ }^{109-111}$ renin activity, ${ }^{112}$ and mRNA for renin and angiotensinogen ${ }^{113}$ in cardiac muscle. Other studies have also provided evidence for a local renin-angiotensin system in the heart. In rats, induced myocardial infarction activates the cardiac but not the circulating renin-angiotensin system. ${ }^{114}$ In end stage cardiac failure, increases in cardiac ACE mRNA levels have been demonstrated. ${ }^{89}$

The idea of an intrinsic cardiac reninangiotensin system with autocrine and paracrine roles remains controversial but the concept is appealing. It has been postulated that a tissue specific renin-angiotensin system, of which the cardiac system may be one, could contribute to long term vascular control depending on the specific needs of the tissue, while the circulating renin-angiotensin system may be primarily involved in acute responses to intravascular volume and sodium changes. ${ }^{108}$ Looking ahead, further elucidation of tissue specific systems has major implications for the possibility of organ specific ACE inhibition. ${ }^{115}$

1 Bright R. Cases and observations illustrative of renal disease accompanied with the secretion of albuminous urine. Guy's Hospital Report 1836;1:338.

2 Olmstead JMD. Charles-Edouard Brown-Sequard: a nineteenth century neurologist and endocrinologist. Baltimore: Johns Hopkins Press, 1946:205.

3 Tigerstedt R, Bergman PG. Niere und kreislauf. Scand Arch Physiol 1898;8:223-70.

4 Tigerstedt R, Bergman PG. The kidneys and the circulation. Scand Arch Physiol 1898;8:223-70, as translated by Ruskin A, in Classics in arterial hypertension. Springfield, IL: Charles C Thomas 1956:273.

5 Shaw HB. Autointoxication: its relation to certain disturbances of blood pressure. Lancet 1906;i:1295-306, 1375-80,1455-62.

6 Ruyter JHC. Uber einen merk wurdigen Abschnitt der Vasa afferentia in der Mauseniere Zeitschrift fur zellforschung. Mikroskopische Anatomie 1925;2:242-8.

7 forschung. Mikroskopische Anatomie 1925;2:242-8. media of the renal arteries. Proc Soc Exp Biol Med 1939; media of

8 Goldblatt $H$, Lynch J, Hanzal RF, Summerville WW. Studies on experimental hypertension: 1 . The production of persistent elevation of systolic blood pressure by tion of persistent elevation of systolic blood pressure by
means of renal ischaemia. $₹$ Exp Med 1934;59:347-80.

9 Pickering GW, Prinzmetal M. Some observations on renin, a pressor substance contained in normal kidney, renin, a pressor substance contained in normal kidney, together with a

10 Landis EM, Montgomery H, Sparkman D. Effects of pressor drugs and of saline kidney extracts on blood
pandis EM, Montgomery $H$, Sparkman D. Effects of pressor drugs and of saline kidney extracts on blood
pressure and skin temperature. F Clin Invest 1938; pressure 
11 Braun-Menendez E, Fasciolo JC, Leloir LF, Munoz JN. The substance causing renal hypertension. 7 Physiol (Lond) 1940;98:293-8.

12 Page IH, Helmer OM. A crystalline pressor substance (angiotonin) resulting from the action between renin and renin-activator. $f \operatorname{Exp} M e d$ 1940;71:29-42.

13 Winternitz MC, Mylon E, Waters LL, Katzenstein R. Studies on the relation of the kidney to cardiovascular disease. Yale $\mathcal{F}$ Biol Med 1939-40;12:623-79.

14 Young HH. Hugh Young: a surgeon's autobiography. New Young HH. Hugh Young: a surgeon's

15 Elliott DF, Peart WS. Amino acid sequence in a hypertensin. Nature 1956;177:527-8.

16 Skeggs LT, Kahn JR, Shumway NP. Preparation and function of the hypertensin-converting enzyme. $f$ Exp Med 1956;103:295-9.

17 Skeggs LT, Kahn JR, Lantz KE, Shumway NP. The preparation, purification and amino-acid sequence of a polypeptide renin substrate. $f$ Exp Med 1957;106: 439-53.

18 Schwyzer R, Sieber P. New synthesis in the peptide field. Chimia 1956;10:265.

19 Inagami T, Misono K, Michelakis AM. Definitive evidence for similarity in the active site of renin and acid protease. Biochem Biophys Res Comm 1974;56:503-9.

20 Simpson SAS, Tait JF. Physicochemical methods of detection of a previously unidentified adrenal hormone. Memoirs of the Society for Endocrinology 1953;2:9-24.

21 Hartroft PM, Hartroft WS. Studies on renal juxtaglomerular cells. II: correlation of the degree of granulation of juxtaglomerular cells with the width of the zona glomerulosa of the adrenal cortex. $\mathcal{F} \operatorname{Exp}$ Med 1955;102: 205-12.

22 Gross $\mathrm{F}$. The discovery of the renin-aldosterone connection. In: Robertson JIS, Brunner $H R$, Hansson $L$, tion. In: Robertson JIS, Brunner $\mathrm{HR}$, Hansson $\mathrm{L}$, Johnson CI, Menard J, Nicholls MG, et al, eds. The

23 Denton DA, Goding JR, Wright RD. Control of adrenal secretion of electrolyte-active steroids. Adrenal stimula-
tion by cross-circulation experiments in conscious tion by cross-circulation experime
sheep. $B M \mp 1959 ; \mathrm{ii}: 448-56,522-30$.

24 Davis JO. Mechanisms regulating the secretion and metabolism of aldosterone in experimental secondary hyperaldosteronism. Rec Prog Horm Res 1961;17: 293-352.

25 Mulrow PJ, Ganong WF. Stimulation of aldosterone secretion by angiotensin II. Yale $\mathcal{F}$ Biol Med 1961;33: 386-95.

26 Davis JO, Hartroft PM, Titus EO, Carpenter CCJ, Ayers $\mathrm{CR}$, Spiegel HE. The role of the renin-angiotensin system in the control of aldosterone secretion. $\mathcal{F}$ Clin Invest 1962;41:378-89.

27 Laragh JH, Angers $M$, Kelly WG, Lieberman S. Hypotensive agents and pressor substances: The effect of epinephrine, norepinephrine, angiotensin II and others on the secretory rate of aldosterone in man. $\mathscr{f} A M A$ 1960;174:234-40.

28 Brown JJ, Davies DL, Lever AF, Robertson JIS. Influence of sodium loading and sodium depletion on plasma renin in man. Lancet 1963;ii:278-9.

29 Brown J, Davies DL, Lever AF, Robertson JIS Variations in plasma renin concentration in several physiological and pathological states. Can Med Assoc 7 1964;90:201-6.

$30 \mathrm{Kliman} \mathrm{B}$, Peterson RE. Isotope derivative assay of aldosterone in biological extracts [abstr]. Fed Proc 1958; 17:255.

31 Lever AF, Robertson JIS, Tree M. The estimation of renin in plasma by an enzyme kinetic technique. Biochem f 1964;91:346-52

32 Boyd GW, Adamson AR, Fitz AE, Peart WS. Radioimmunoassay determination of plasma-renin activity. Lancet 1969;i:213-8.

33 Oparil S, Haber E. The renin-angiotensin system. $N$ Engl f Med 1974;291:389-401.

34 Brown J, Fraser R, Lever AF, Love DR, Morton J, Robertson JIS. Raised plasma angiotensin II and aldosterone during dietary sodium restriction in man. Lancet 1972;ii:1106-7.

35 Oelkers W, Brown J, Fraser R, Lever AF, Morton JJ, Robertson JIS. Sensitization of the adrenal cortex to angiotensin II in sodium deplete man. Circ Res 1974; 34:69-77.

36 Brown JJ, Casals-Stenzel J, Cumming AMM, Davies DL, Fraser R, Lever AF, et al. Angiotensin II, aldosterone and arterial pressure. A quantitative approach. and arterial pressure. A

37 Brown AJ, Casals-Stenzel J, Gofford S, Lever AF, Morton JJ. Comparison of fast and slow pressor effects of JJ. Comparison of fast and slow pressor effects of
angiotensin II in the conscious rat. Am $\mathcal{F}$ Physiol 1981; 241: H381-8.

38 Wolff HP, Koczorek KHR, Buchborn E, Kuehler M. Ueb Hierzkranken und ihre Pathophysiologische bei Hierzkranken und ihre Pathophysio
Bedeutung. Klin Wochenschr 1956;34:1105-14.

39 McAlpine HM, Cobbe SM. Neuroendocrine changes in acute myocardial infarction. Am $\mathcal{F}$ Med 1988;84(suppl $3 \mathrm{~A}): 61-6$

40 Brunner HR, Laragh JH, Baer L, Newton MA, Goodwin FT, Krakoff LR, et al. Renin and aldosterone, heart attack and stroke. N Engl ₹ Med 1972;286:441-9.

41 Laragh $\mathrm{JH}$. The renin system and four lines of hypertension research. Hypertension 1992;20:267-79.

42 Koch-Weser J. Nature of the inotropic action of angiotensin on the ventricular myocardium. Circ Res 1965;16:230-7.

43 Baker KM, Khosla MC. Cardiac and vascular actions of decapeptide angiotensin analogs. F Pharmacol Exp Ther 1986;239:790-6.

44 Jin $M$, Wilhelm MJ, Lang RE, Unger T, Lindpainter $K$, Ganten D. Endogenous tissue renin-angiotensin systems. $A m \dot{f}$ Med 1988;84(suppl 3A):28-36.

45 Gavras H, Kremer D, Brown JJ, Gray B, Lever AF, Macadam RF, et al. Angiotensin and norepinephrineinduced myocardial lesions: Experimental and clinical studies in rats and man. Am Heart $f 1975 ; 89: 321-32$.

46 Kremer D, Lindop G, Brown WCB, Morton J, Robertson JIS. Angiotensin-induced myocardial necrosis and renal failure in the rabbit: Distribution of lesions and severity in relation to plasma angiotensin II concentration and blood pressure. Cardiovasc Res 1981; 15:43-6.

47 Mancia G, Romero JC, Shepherd JT. Continuous inhibition of renin release in dogs by vagally innervated receptors in the cardiopulmonary region. Circ Res 1975;36: 529-35.

48 DeBold AJ, Borenstein HR, Veress AT, Sonnenberg H. A rapid and potent natriuretic response to intravenous injection of atrial myocardial extracts in rats. Life Sci 1981;28:89-94.

49 Richards AM, Tonolo G, Tree M, Robertson JIS, Montorsi P, Leckie BJ, et al. Atrial natriuretic peptides and renin release. $A m \mathcal{F} M e d$ 1988;84(suppl 3A):112-8.

50 Cody RJ, Atlas SA, Laragh JH, Kubo SH, Covit AB, Ryman KS, et al. Atrial natriuretic factor in normal subjects and heart failure patients: plasma levels and renal, sion. $f$ Clin Invest 1986;78:1362-74.

51 Ferreira SH. A bradykinin-potentiating factor (BPF) present in the venom of Bothrops jararaca. Br $\mathcal{Y}$ Pharmacol 1965;24:163-9.

52 Erdos EG, Sloane EM. An enzyme in human blood plasma that inactivates bradykinin and kallidins. plasma that inactivates bradykini

53 Bakhle YS. Conversion of angiotensin I to angiotensin II by cell-free extracts of dog lung. Nature 1968;220: 919-21.

54 Engel SL, Schaeffer TR, Waugh MH, Rubin B. Effects of the nonapeptide $S Q 20881$ on blood pressure of rats with experimental hypertension. Proc Soc Exp Biol Med 1973;143:483-7.

55 Samuels AI, Miller ED, Fray CS, Haber E, Barger AC. Regulation of pressure by the renin-angiotensin system [abstr]. Fed Proc 1973;32:380.

56 Yang HYT, Erdos EG, Levin Y. Characterization of a dipeptide hydrolase (kininase II; angiotensin I converting enzyme) 7 Pharmacol Exp Ther 1971;117:291-300.

57 Pals DT, Masucci FD, Sipos F, Denning GS. Specific competitive antagonists of the vascular action of angiotensin II. Circ Res 1971;29:664-72.

58 Gavras I, Gavras H. Angiotensin II-possible adverse effects on arteries, heart, brain and kidney: experimental, clinical and epidemiological evidence. In: Robertson JS, Nicholls MG, eds. The renin-angiotensin system. New

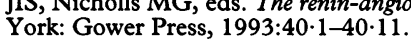

59 Johnson JA, Davis JO. Effects of a specific competitive antagonist of angiotensin II on arterial pressure and antagonist of angiotensin II on arterial pressure and 159-68.

60 Brunner HR, Gavras H, Laragh JH, Keenan R Hypertension in man: Exposure of the renin and sodium components using angiotensin II blockade. Circ Res 1974;34/35 (suppl 1):35-43.

61 Brown JJ, Brown WCB, Fraser R, Lever AF, Morton JJ, Robertson JIS, et al. The effects of the angiotensin II antagonist saralasin on blood pressure and plasma aldosterone in man in relation to the prevailing plasma angiotensin II concentration. In: Stokes GS, Edwards KDG, eds. Drugs affecting the renin-angiotensin system. Use of angiotensin II inhibitors. Prog Biochem Pharmacol 1976;12:230-1.

62 Timmermans PBMWM, Carini DJ, Chiu AT, Duncia JV, Price WA, Wells GJ, et al. The discovery of a new class of highly specific nonpeptide angiotensin II receptor antagonists. Am f Hypertension 1991;4(suppl):275-8.

63 MacFadyen RJ, Reid JL. Angiotensin receptor antagonists as a treatment for hypertension. 7 Hypertens 1994;12. 1333-8.

64 Poulsen K, Burton J, Haber E. Competitive inhibitors of renin: a review. Prog Biochem Pharmacol 1976;12: renin: a

65 Szelke M, Leckie B, Hallett A, Jones DM, Sueiras J, Atrash B, et al. Potent new inhibitors of human renin. Atrash B, et al. Potent
Nature 1982;299:555-7.

66 Veterans Administration Cooperative Study Group. Captopril: Evaluation of low doses, twice-daily doses Captopril: Evaluation of low doses, twice-daily doses and the addition of diuretic for the treatment of mild-to-
moderate hypertension. Clin Sci 1982;63 (suppl 18): moderate

67 Davis R, Ribner HS, Keung E, Sonnenblick EH, LeJemtel TH. Effect of captopril in heart failure. $N$ Engl $₹ \mathrm{Med}$ TH. Effect of captop

68 Turini GA, Brunner HR, Gribic M, Waeber B, Gavras H. Improvement of chronic congestive heart failure by oral captopril. Lancet 1979;i:1213-5.

69 Furberg CD, Yusuf $S$. Effect of vasodilators on survival in chronic congestive heart failure. Am $\mathcal{f}$ Cardiol 1985;55: 1110-11. 
70 The CONSENSUS Trial Study Group. Effects of enalapril on mortality in severe heart failure. $N$ Engl $\mathcal{F}$ Med 1987;316:1429-35.

71 SOLVD Investigators. Effect of enalapril on survival in patients with reduced left ventricular ejection fraction and congestive heart failure. $N$ Engl $\mathcal{F}$ Med 1991;325 293-302.

72 SOLVD Investigators. Effect of enalapril on mortality and the development of heart failure in asymptomatic patients with reduced left ventricular ejection froctions. N Engl F Med 1992;327:685-91.

73 Pfeffer MA, Braunwald E, Moye LA, Basta L, Brown EJ, Cuddy TE, et al. Effect of captopril on mortality and morbidity in patients with left ventricular dysun an morbidity in patients with left ventricular dysfunction Ventricular Enlargement Trial. $N$ Engl $f$ Med 1992; 327:669-77.

74 Casale PN, Devereux RB, Milner M, Zullo G, Harshfield GA, Pickering TG, et al. Value of echocardiographic measurement of left ventricular mass in predicting car-
diovascular morbid events in hypertensive men. Ann diovascular morbid events
Intern Med 1986;105:173-8.

75 Levy D, Garrison RJ, Savage DD, Kannel WB, Castell WP. Left ventricular mass and incidence of coronary heart disease in an elderly cohort: the Framingham Heart Study. Ann Intern Med 1989;110:101-7.

76 Pfeffer JM, Pfeffer MA, Mirsky I, Braunwald E. Regression of left ventricular hypertrophy and prevention of left ventricular dysfunction by captopril in the spontaneously hypertensive rat. Proc Natl Acad Sci USA 1982;79:3310-4

77 Dahlöf B, Pennerty K, Hansson L. Regression of left ventricular hypertrophy. A meta-analysis. Clin Exp Hypertens 1992;A14:173-80.

78 Devereux RB, Pickering TG, Cody RJ, Laragh JH. Reaction of renin-angiotensin system to left ventricular hypertrophy and function in experimental and human hypertension. $\mathcal{f}$ Clin Hypertens 1987;3:87-103.

79 Michel JB, Salzmann JL, Cerol ML, Dussaule JC, Azizi $\mathrm{M}$, Corman B, et al. Myocardial effect of converting enzyme inhibition in hypertensive and normotensive rats. $A m \mathcal{f} M e d$ 1988;34(suppl 3A):12-21.

80 Morgan HE, Baker KM. Cardiac hypertrophy: mechanical, neural and endocrine dependence. Circulation cal, neural and

81 Campbell-Boswell M, Robertson AL. Effects of angiotensin II and vasopressin on human smooth muscle cells tensin II and vasopressin on human smoo
in vitro. Exp Mol Pathol 1981;35:265-76.

82 Baker KM, Aceto JF. Angiotensin II stimulation of protein synthesis and cell growth in chick heart cells. $A m \mathcal{F}$ tein synthesis and cell grow

83 Pratt RE, Dzau VJ. Trophic effects of angiotensin on blood vessels and heart. In: Robertson JIS, Nicholl MG, eds. The renin-angiotensin system. New York Gower Press, 1993:31·1-31·7.

84 Ertl G. Coronary vasoconstriction in experimental myocardial ischaemia. $\mathcal{F}$ Cardiovasc Pharmacol 1987;9 (suppl 2):s9-17.

85 Magrini F, Reggiani P, Roberts N, Meazza R, Ciulla M Zanchetti A. Effects of angiotensin and angiotensin blockade on coronary circulation and coronary reserve. Am f Med 1988;84(suppl 3A):55-60.

86 Linz W, Schölkens BA, Han YF. Beneficial effects of the converting enzyme inhibitor, ramipril, in ischaemic rat hearts. 7 Cardiovasc Pharmacol 1986;8(suppl 10):s91-9.

87 Foult JM, Tavoloro O, Anthony I, Nitenberg A. Direct myocardial and coronary effects of enalaprilat in bilateral intracoronary infusion technique. Circulation 1988;77:337-44.

88 Faxon DP, Creager MA, Halperin JL, Sussman HA Gavras H, Ryan TJ. The effect of angiotensin converting enzyme inhibition on coronary blood flow and hemodynamics in patients without coronary artery disease. Int $\mathcal{f}$ namics in patients without

89 Holtz J. Pathophysiology of heart failure and the reninangiotensin system. Basic Res Cardiol 1993;88(suppl 1): 183-201.

90 Rousseau MF, Gurne O, Van-Eyll C, Benedict CR Pouler $\mathrm{H}$. Effects of benazeprilat on left ventricular systolic and diastolic function and neurohumoral status in patients with ischaemic heart disease. Circulation 1990; 81(suppl III): 123-9.

91 Bickerton RK, Buckley JP. Evidence for a central mechanism in angiotensin-induced hypertension. Proc Soc Exp Biol Med 1961;106:832-46.

92 Zimmerman BG. Effect of acute sympathectomy on responses to angiotensin and norepinephrine. Circ Res
1962;11:780-7

93 Braun-Menendez E, Fasciolo JC, Leloir LJ, Munoz JM Taquini AC. Renal hypertension. Springfield, IL Charles C Thomas, 1946.

94 Crozier IG, Theo R, Kay R, Nicholls MG. Sympathetic nervous system during converting enzyme inhibition. Am $\mathcal{F}$ Med 1989;87(suppl 6B):29-32.

95 Dzau VJ. Cardiac renin-angiotensin system. Molecular and functional aspects. Am 7 Med 1988;84(suppl 3A): 22-7.

96 DeGraeff PA, deLangen CDJ, vanGilst WH, Bel K, Scholtens E, Kingma JH, et al. Protective effects of captopril against ischaemia/reperfusion-induced ventricular arrhythmias in vitro and in vivo. Am $\mathcal{F}$ Med 1988; 84(suppl 3A):67-74.

97 Pfeffer JM, Pfeffer MA. Angiotensin converting enzyme inhibition and ventricular remodelling in heart failure. inhibition and ventricular remodelling

98 Gavras H, Gavras I. Cardioprotective potential of angiotensin converting enzyme inhibitors. $\mathcal{F}$ Hyperten angiotensin conve

99 Schölkens BA, Linz W, Konig W. Effects of the angiotensin inhibitor, ramipril, in isolated ischaemic rat heart are abolished by a bradykinin antagonist. $\mathcal{F}$ Hypertens 1988;6(suppl 4):525-8.

100 Linz W, Schölkens BA. Bradykinin receptor antagonist abolishes the antihypertrophic effect of ramipril. In Bonner G, Schölkens BA, Scicli AG, eds. The role of bradykinin in the cardiovascular action of ramipril. Weissbaden: Media Medica, 1991:85-9.

101 Vanhoutte PM, Boulanger CM, Vidal M, Mombouli JV. Endothelium-derived mediators and the reninangiotensin system. In: Robertson JIS, Nicholls MG eds. The renin-angiotensin system. New York: Gowe Press, 1993:29.1-29.15.

102 Chobanian AV, Haudenschild CC, Nickerson C, Drago $R$. Antiatherogenic effect of captopril in the Watanabe heritable hyperlipidaemic rabbit. Hypertension 1990;15: 327-31.

103 Powell JS, Clozel JP, Mullere RKM, Kuhn H, Hefti F, Hosang $\mathrm{M}$, et al. Inhibitors of angiotensin-converting enzyme prevent myointimal proliferation after vascular injury. Science 1989;245:186-8.

104 Rigat B, Hubert C, Alhenc-Gelas F, Cambien F, Corvol $P$, Soubrier F. An insertion/deletion polymorphism in the angiotensin I converting enzyme gene accounting for the angiotensin I converting enzyme gene accounting for half the variance

105 Cambien F, Poirier O, Lecerf L, Evans A, Cambon JP, Arveiler D, et al. Deletion polymorphism in the gene for angiotensin converting enzyme is a potent risk factor for myocardial infarction. Nature 1992;359:641-4.

106 Hayduk K, Boucher R, Genest J. Renin activity and content in various tissues in dogs under different pathophysiological states. Proc Soc Exp Biol Med 1970;134 252-5.

107 Needleman P, Marshall GR, Sobel BE. Hormone interactions in the isolated rabbit heart. Circ Res 1975;37. 802-8.

108 Campbell DJ. Circulating and tissue renin-angiotensin systems. F Clin Invest 1987;79:1-6.

109 Cohen ML, Kurz KD. Angiotensin converting enzyme inhibition in tissues from spontaneously hypertensive
rats after treatment with captopril or MK421. F Pharmacol Exp Ther 1982;220:63-9.

110 Unger T, Ganten D, Lang RE, Schölkens BA. Is tissue converting enzyme inhibition a determinant of the antihypertensive efficacy of converting enzyme inhibitors? Studies with two different compounds, Hoe-498 and MK-421, in spontaneously hypertensive rats. $f$ Cardiovasc Pharmacol 1984:6:872-80.

111 Lindpainter $\mathrm{K}$, Wilhelm $\mathrm{M}$, Jin $\mathrm{M}$, Unger $\mathrm{T}$, Lang RE Ganten D. Tissue renin-angiotensin systems: focus on Ganten $D$. Tissue renin-angiotensin system
the heart. $f$ Hypertens $1987 ; 5$ (suppl 2 ):s33-8.

112 Dzau VJ, Re RN. Evidence for the existence of renin in the heart. Circulation 1987;73(suppl I):134-6.

113 Dzau VJ, Brody T, Ellison KE, Pratt RE, Ingelfinger JR Tissue-specific regulation of renin expression in the mouse. Hypertension 1987;9(suppl III):36-41.

114 Hirsc AT, Talsness CE, Schunkert H, Paul M, Dzau VJ. Tissue-specific activation of cardiac angiotensin converting enzyme in experimental heart failure. Circ Res 1991;69:475-82.

115 Cushman DW, Wong FL, Fung WC, Harvey CM DeForrest JM. Differentiation of angiotensin convertin enzyme (ACE) inhibitors by their selective inhibition of ACE in physiologically important target organs. $A m$ Hypertens 1989;2:294-306. 